\title{
Родословная Кыргысов из Эйлиг-Хема (Тува)
}

\author{
Чойганмаа К. Ойдуп \\ Тувинский институт комплексного освоения природных ресурсов СО РАН, \\ Российская Федерация
}

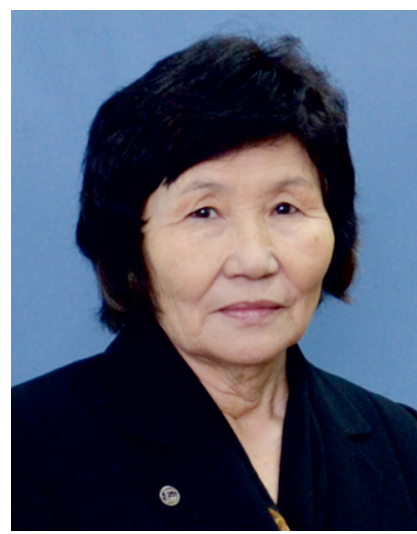

Жизнь тувинских родов в ХХ веке претерпела значительные изменения: седентаризация, переезды, изменение личных данных людей в связи с паспортизацией 1940-х г2., потери родственников. Нынешнее стремление тувинцев к восстановлению родословных имеет много проблем с установленных данных на людей. Это показано на примере истории одного рода - Кыргысов из Эйлиг-Хема Улуг-Хемского района Тувы, которую восстанавливает автор статьи, представитель этого рода. Информация восстанавливалась из рассказов родителей автора, детских воспоминаний, а также сообщений сестер - старшей родной Лидии Кыргысовны Будуп (1943 г.р.) и сродной (по линии отца) Валентины Одурековны Домур-оол (1943 г.p.).

Описана история жизни родителей Седиваа Сатовны Шагдыр (1918-1988) и Кыргыса Будуповича Шагдыра (1915-1987), поведаны семейные истории хан-төрел - родных по крови людей. Автор отмечает сколько детей, внуков и правнуков сегодня насчитывает род, где они проживают. Представлено родословное древо, которое удалось составить.

Представители рода сегодня стараются не терять связи друг с другом, встречаются на родовых дагылга (обрядах освящения) в местах, где проживали их предки в УлугХемском районе.

Ключевые слова: тувинцы; паспортизация; советская Тува; родословная; родственные связи; родственная группа; семья; Кыргыс; Сат; биография

\footnotetext{
Ойдуп Чойганмаа Кыргысовна - кандидат геолого-минералогических наук, ведущий научный сотрудник Тувинского института комплексного освоения природных ресурсов СО РАН. Адрес: 667007, Россия г. Кызыл, ул. Интернациональная, 117а. Эл. адрес: oydup_ch@mail.ru
}

OYDUP, Choyganmaa Kyrgysovna, Candidate of Geological and Mineralogical Sciences, Leading Scientific Collaborator, Tuvan Institute for Complex Development of Natural Resources, Siberian Branch, Russian Academy of Sciences. Postal address: 117a Internatsionalnaya Street, Kyzyl, Russian Federation.667007.E-mail: oydup_ch@mail.ru 


\title{
The Genealogy of the Kyrgys from Eylig-Khem (Tuva)
}

\author{
Choyganmaa K. Oydup \\ Tuvan Institute for Complex Development of Natural Resources, Siberian Branch, Russian Academy of Sciences, \\ Russian Federation
}

\begin{abstract}
The life of Tuvan clans in the 20th century underwent significant changes: sedentarization, relocations, changes in the personal data of people due to the passportization of the 1940s, losses of relatives. The current desire of the Tuvans to restore family trees causes many problems with collection of data on people. This is shown by the example of the history of an ancestry - the Kyrgys from EyligKhem in the Ulug-Khem district of Tuva. The author of the article, a representative of this family, restores their history. The information was taken from the stories told by the author's parents, childhood memories, and messages from her sisters - the full elder one, Lydia Kyrgysovna Budup (born in 1943), and the kindred sister (from the father's side), Valentina Odurekovna Domur-ool (born in 1943).

The article describes the life history of the author's parents, Sedivaa Satovna Shagdyr (1918-1988) and Kyrgys Budupovich Shagdyr (1915-1987); family histories of khan-terel - the kindred people - are presented. The author notes how many children, grandchildren and great-grandchildren there are in the family where they dwell today. The family tree that we have managed to compile is presented.

Representatives of the kinship group today try not to lose touch with each other, they meet at the family dagylga (consecration rites) in the places where their ancestors lived in the Ulug-Khem district.
\end{abstract}

Keywords: Tuvans; passportization; Soviet Tuva; family tree; kinship ties; kinship group; family; Kyrgys; Sat; biography

For citation:

Oydup Ch. K. Rodoslovnaia Kyrgysov iz Eilig-Khema (Tuva) [The Genealogy of the Kyrgys from Eylig-Khem (Tuva)]. New Research of Tuva, 2021, no. 4, pp. 46-56. (In Russ.). DOI: https://www.doi.org/10.25178/nit.2021.4.4

\section{Введение}

Тувинцы изревле были обязаны знать свою родословную и имена предков до девятого колена (Кенин-Лопсан, 2006: 52-54). Родовые общности жили на одной территории, знания передавались из уст в уста новым поколениям, что позволяло поддерживать традицию.

Однако сейчас этот путь во многом утрачен. Например, я и мои родные помнят только родителей мамы - Серена и Севил, которые жили в 1880-1946 гг. по долине рек Большие и Малые Уры (с 1944 года территория отошла Красноярскому краю), и папы - Будупа и Кушкаш, обитавших в 1880-1960 гг. в долине рек Эйлиг-Хем и Куйлуг-Хем Улуг-Хемского района. Наше генеалогическое древо фактически начинается с них, потому что ни документов, ни записей прародителей не было из-за отсутствия письменности.

После вхождения Тувы в состав СССР, когда каждому жителю надо было оформить паспорт, тувинцам стали присваивать новые данные, в том числе давать фамилии, которых у них раньше не было. Основной рекомендацией власти был выбор в качестве фамилии собственного имени, имени отца или деда. Если выбиралось первое - то следовало придумать новое собственное имя. Например, у моего одноклассника имя матери было Содунам, при паспортизации ей предложили имя сделать 
фамилией, а себе придумать новое имя. Так она стала Содунам Варвара Кыргысовна. Многие тувинцы поменяли или придумали себе фамилии, имена. На мой взгляд, в результате этой кампании началась большая путаница, в том числе поломалось представление о родовой последовательности. Это сейчас значительно затрудняет задачу восстановления родословных.

Посмотрим на примере одной из родственных групп тувинцев - родственников автора статьи - как восстанавливалась информация для родословной и с какими сложностями приходится сталкиваться. Речь идет о хан-төрел (родных по крови) Кыргыс из Эйлиг-Хема Улуг-Хемского района, в частности о семье - өг-бүле Шагдыр. Информация восстанавливалась из рассказов родителей автора, детских воспоминаний, а также сообщений сестер - старшей родной Лидии Кыргысовны Будуп (1943 г.р.) и сродной (по линии отца) Валентины Одурековны Домур-оол (1943 г.р.).

\section{История мамы из рода Сат}

Моя мама Шагдыр Седиваа Сатовна (1918-1988) (фото 1) из Сатmар бөлүү (рода Сатов). Они жили и кочевали в долине рек Большие и Малые Уры. До 1944 г. здесь - по Усинскому району - проходила пограничная зона между Тувинской Народной Республикой и Красноярской губернией, затем - Шушенским районом Красноярского края.

Границы государств устанавливались преимущественно по очень приметным объектам - хребтам или водоразделам. Так, хребты Западных Саян раньше были северной границей Тувы. Упоминания о тувинцах, проживавших здесь, собраны в работе В. Г. Дацышена (Дацышен, 2005: 20-24).

Долина рек Большие и Малые Уры - благодатное место для животноводства. Территория просторная, наполненная зеленью, поскольку южные склоны хорошо освещены солнцем. Со слов моей матери (она вспоминала детство), ее родные активно перемещались на лошадях вниз по левой стороне Енисея до Ур-Сайлыг. По Малой Уре жили родные нашей бабушки (матери мамы).

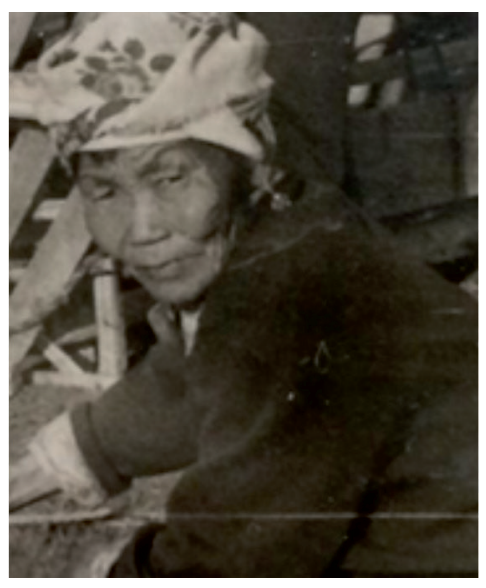

Фото 1. Шагдыр Седиваа Сатовна, 1978 г. Фото из личного архива автора.

Photo 1. Shagdyr Sedivaa Satovna, 1978.

Тувинцы соседствовали с русскоязычным населением. Все обща- Photo from the author's personal archive. лись, несмотря на языковой барьер, и обогащали лексикон друг дру-

га. У мамы в обиходе были русские слова: «помощь», «газета», «просо», «орех» и т. д. Кроме этого, жители долины держали связь с жильцами из долин рек Үрбун, Чинге, Орта-Хем, Куйлуг-Хем, ЭйлигХем (правые притоки Енисея) и Чаа-Хөл (левый приток). Перемещались преимущественно на плотах по Енисею (зимой - по льду), но были и тропы вдоль берегов - по ним ездили на лошадях. Связь с жителями выше по течению Енисея была постоянная и крепкая. Это было необходимо, поскольку люди обменивались разной продукцией. По рассказам мамы, когда началось вытеснение тувинцев из этих территорий в 1944-1945 гг., часть жителей поднялась по Енисею выше, а часть спустилась к долине р. Ус ниже по течению реки. Родители мамы до последних дней своей жизни оставались там.

Кырган-ачавыс (наш дедушка) по имени Серен (чаще его звали Кара-Кежеге - из-за черных, кучерявых волос, о чем нам рассказывала мама) жил в 1888-1946 гг., а кырган-ававыс (бабушка) Севил - в 1890-1944 гг. У них было 6 детей: три сына и три дочери. Мама была пятой (двух ее старших братьев мы не знаем, они умерли рано), двух старших сестер - наших теть (даай-ававыс) - звали Суваң (1912-1978) и Сиилиң (1915-1997), и младший - шестой ребенок в семье даайывыс (наш дядя) Даш (1922-1965). Обеих теть и дядю мы знали хорошо, общались до последних дней их жизни.

Характеризуя внешность рода Сат, могу сказать следующее: они среднего роста, овальное лицо с короткими носами, светлая кожа, редкие черные волосы. Цвет глаз не карие, как у рода Кыргыс, а более светлые шаңдыр, т. е. цвет недоспелого крыжовника. Такие же черные и кучерявые, как у деда, волосы были у его родной сестры - кырган-авай, так мы ее называли, Суруң. Она тоже была сосватана оттуда и жила в Эйлиг-Хеме. У нее была непростая судьба: муж Чалбаа Шагдыр-Суруң оглу, участник Ховдинской войны (1911 г.), был ранен и умер в возрасте 48 лет. Она вырастила детей одна. Приметными кудрями был наделен только старший внук нашей тети. 
Нашу маму сосватали в 1936 г., когда ей было 18 лет. В те времена с желаниями жениха и невесты не считались, учитывали только ук, угун уктаар (наследственность) и ызыгуур салгаан (наследные вопросы). До замужества ее звали Седиваа Серен уруу. По итогам паспортизации она стала Шагдыр Седиваа Сатовна (так как она была замужем за Шагдыр, соответственно ее записали по мужу). Мама рассказывала, что она хотела остаться Сат Седиваа Сереновной. Но большими спорами она добилась, чтоб ее записали хотя бы «Сатовной». А удалось это сделать благодаря тому, что она умела читать и писать, и вовремя успела заметить, что ей пишут «Кыргысовна», как остальным. А сколько таких было безграмотных тувинцев, которые даже не могли прочитать и понять, как им приписывают новые имена!..

Маме удалось научиться грамоте, когда она переехала к мужу. Тогда по долинам, где больше всего располагалось аалов, были организованы кызыл булун - красные уголки, юрты-школы. В них люди обучались старотувинской письменности на латинизированном алфавите. Потом старших детей мама обучала этому алфавиту еще до школы. Как вспоминает моя старшая сестра, «где только не писали на буржуйке угольком, на бересте. Когда пришла в первый класс, то быстро научилась читать, хотя уже был русский алфавит».

Родители очень сожалели о смене алфавита, так как новые книги, газеты стали недоступны им. Они так всю жизнь и писали латинизированными буквами для себя. Писать и считать им было важно для того, чтобы вести строгий учет коз. В прошитых школьных тетрадях записывалась каждая коза с госномером (он был указан на железной бирке, которая висела у каждого животного на ухе), сколько козлят у нее, какой масти, номера их сначала временных бирок на шее...

Дома у нас были два небольших апmара (сундука), у которых были съемные крышки: одна использовалась как доска для раскатывания лепешек со скалкой, на другой было нарисовано поле бугашыдыраа (тувинские шахматы, см.: Самбуу, 1992: 51-53). Мама говорила, что с этими двумя сундуками она и приехала в Эйлиг-Хем, это было ее приданое.

В сундуках, помимо прочего, хранился саадак. Так она называла сумку из тонкого войлока, сотканную из белой шерсти, с длинной ручкой из шерсти. В ней хранились самые ценные документы: паспорта родителей, свидетельства о рождении детей, документы на ружья, охотничий билет, облигации (их покупали во время Великой Отечественной войны, см.: Харунова, Харунов, Базыр, 2020). Также в ней лежали и лекарства: тооргу хини (струя кабарги), адыг өдү (желчь медведя), сыын мыйызы (кусок рога марала), хая чугу (каменная смола), кургаткан чуңма ханы (сушеная кровь дикой козы) и т. д. - всего по чуть-чуть. Мы, дети, никогда не трогали сумку, она хранилась глубоко на дне сундука. Родители знали когда, что достать, если дети или они сами захворают. Сумочка была очень дорога маме, так как она соткала ее сама.

Бабушка - мама моей мамы - умерла в возрасте 54 лет, а дед спустя два года - в возрасте 58 лет. Изза отсутствия скорой связи, дальности расстояния и сложности перемещения (на плотах, по льду зимой), мама была на похоронах только дедушки в 1946 г., и то с опозданием.

Наша мама умерла в 1988 г., оставив после себя 9 детей (в том числе и приемного сына). От 9 детей появилось 26 внуков, 48 правнуков, 8 праправнуков, о которых я скажу далее.

\section{История отца из рода Кыргыс}

По линии отца Шагдыра Кыргыса Будуповича (1915-1987) (фото 2) мы относимся к роду Кыргыс, которые населяли долины рек Куйлуг-Хем, ЭйлигХем, Демир-Суг (правые притоки Енисея), начиная от г. Буура далее на запад цепь вытянутых хребтов Ийме вдоль правой стороны Енисея. На севере граница земель проходит по Куртушибинскому хребту.

Стоянка нашей семьи называлась Чангыс Шиви ('Одинокая ель'), куда мы спускались после чайлаг (летников) и кыштаг (зимника). Она находилась в 4-5 км к северу от могильника Бедик Хорум, который был открыт советским археологом А. Д. Грачом и который остается крупнейшим памятником периода экспансии енисейских кыргызов не только в Туве, но и в

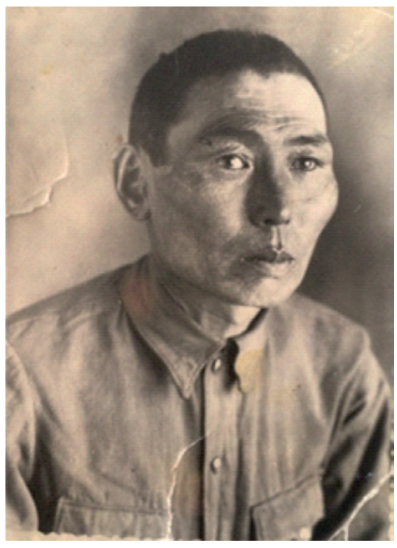

Фото 2. Шагдыр Кыргыс Будупович, 1956 г. Фото из личного архива автора. Photo 2. Shagdyr Kyrgys Budupovich, 1956. Photo from the author's personal archive. 
Центральной Азии в целом (Грач, Савинов, Длужневская, 1998). Вся долина нижнего течения р. ЭйлигХем была пахотной, ее активно использовали в первой половине XX в. Забросили только в 1959 г., когда был организован совхоз «Свобода труда» и здесь стал разводиться только мелкий рогатый скот.

Отары паслись вокруг могильника, но на само сооружение нельзя было подниматься. Родители нам велели не осквернять место, так как, считалось, что там находится могила владыки этой долины.

По внешности Кыргысы имеют вытянутое лицо с длинным носом. Таким был мой отец, волосы у него были густые и седые. Еще одна особенность Кыргысов - высокий рост. У отца был рост 193 см, такой же статной была его мама. Причем этот рост считается очень высоким даже для современных тувинцев. Кыргысов, на мой взгляд, отличает стойкость в своих убеждениях, умение отстаивать своё родное.

Представители рода Кыргыс (кыргыстар), проживавшие по долине рр. Эйлиг-Хем, Демир-Суг, Куйлуг-Хем, старались связываться родством с жителями долин рек: Большие и Малые Уры, Хем-Теректиг (род Сат), Урбун (род Донгак), Эжим (род Ховалыг) и верховье р. Уюк (Тарлаг, Хадын) (род Маады).

Наш отец Шагдыр Будуп оглу родился в 1915 г. По итогам паспортизации он стал Шагдыр Кыргыс Будупович. Имя рода стало его именем и соответственно мы - дети - «потеряли» правильное отчество. Мать его звали Кушкаш. Она родилась в 1880 г., а умерла в мае 1952 г. в возрасте 72 лет. Я помню хлопоты, связанные со смертью бабушки, хотя мне не было еще трех лет. Отца моего отца, т. е. моего деда, звали Будуп, годы его жизни 1877-1960 гг.

Мы с детских лет заметили, что родители не любили рассказывать историю отца. Начальную школу я окончила в Эйлиг-Хеме и жила у одного из родственников. У него дома видела фотографии, на которых замечала сходство не самых близких родственников. Лишь много позже мы поняли, почему эта тема была практически под запретом.

Отсутствие медицинской помощи в старые времена приводило к тому, что не каждая семья могла иметь ребенка. Наш род находил решение в этом деликатном вопросе, выручая друг друга азырантыга дилеп алыр (дарением, усыновлением) ребенка.

Мы считаем нашими предками двух двоюродных братьев Кошкар-оола и Көка, а также двоюродную сестру Кушкаш - маму отца. Она была самой авторитетной, уважаемой женщиной, которую было принято слушаться, подчиняться, ей не смели перечить. Их отцы были родными братьями. Самого старшего из них Кошкар-оола мы не застали, он был многодетным отцом, имел пятерых сыновей и младшую дочь Караш. С дедушкой Көк я была знакома, так как жила у него, учась в начальной школе.

Говорят, что нашей бабушке Кушкаш молитвы лам помогли родить девочку - старшую сестру отца Седип. Но больше детей у нее не было. Поэтому у многодетного брата Кошкар-оола она попросила усыновила в младенчестве его четвертого сына - нашего отца. А у Көк вовсе не было детей. Он удочерил дочь Кошкар-оола - Караш, причем после его смерти.

То, что и наш старший брат - приемный ребенок - я и все остальные узнали, когда я училась в 9 классе. Случайно в столовой городка Шагонар я увидела молодого человека, необычайно похожего на нашего старшего брата. Он был в военной форме, но, если мой брат вернулся чуть пораньше, отслужив в погранвойсках на о. Кунашир, то его двойник был в форме других рода войск. На выходные я пришла домой и задала вопрос родителям «в лоб». Тут они и поведали историю: они потеряли двоих старших детей подряд, младенцы не доживали до года. В этой связи, чтоб остановить этот «процесс», бабушка вынесла такое решение - им надо было усыновить ребенка. У дальних родственников в это время родились двойняшки, вот у них и «попросили» одного из них, в двухмесячном возрасте. Потери в самом деле остановились. Через два года у родителей родилась девочка - моя старшая сестра Лида. Таким образом нас с братом насчитывается 9 человек.

Родители отца были состоятельными людьми, причем основным богатством тогда считался чеди чүзүн малы - скот. Но при коллективизации (1934-1935 гг.) и при создании колхоза в 1949 г., весь скот национализировали. Им не удалось передать хозяйство сыну и дочери - нашему отцу и его старшей сестре. Остались только одна корова, конь и 5-6 голов овец. Бабушка не приняла такой расклад, все восприняла в «штыки». В знак протеста новым порядкам бабушка Кушкаш даже отказалась отдать в школу нашу старшую сестру. Та пошла в школу в возрасте 9 лет только после смерти бабушки. Тогда же в 1952 году маме и кырган-ачам (отцу нашего папы) удалось вступить в колхоз и получить стадо коз, около ста голов. 
Также негативно воспринимали новшества братья бабушки Кушкаш и их дети. Племянник бабушки Дору-Сүрүң, старший сын Кошкар-оола, из-за своего неприятия новой власти получил прозвище Кондр (тувинизированное «контра») Дору-Сүрүң в 1935г. Два его младших брата в начале 1950-х годов вынуждены были перебраться на родину матери в долину Уюк. Папа говорил, что им пришлось поменять со временем и фамилии из-за преследования, на какие именно - не припоминаю. ДоруСүрүң рано ушел из жизни, когда его младшему сыну не было и двух лет. Впоследствии его усыновил Көк. Два старших ребенка Дору-Сүрүң - сын и дочь - при паспортизации поменяли свои фамилии на Тюлюш и уехали в Чаа-Хөл, где преимущественно проживал род Тюлюш. Сын получил хорошее образование, работал по линии партии. В последние годы жизни работал заместителем председателя республиканского КГБ по кадрам. Сестра его в конце 1950-х годов вернулась в Эйлиг-Хем, приняла отару, стала работать чабаном. Передовиками-чабанами стали и ее сын и младшая дочь.

Более-менее без особых неприятностей этот сложный период пережил Көк благодаря күдээ (зятю) Тюлюш Өдүрек, мужу старшей его дочери Караш. Тот стал первым специалистом во вновь организованном колхозе в Эйлиг-Хеме. Младший (усыновленный) сын выучился на бухгалтера, долгие годы работал в совхозе «Свобода труда».

В целом члены нашего хан төрел Кыргыс из Эйлиг-Хема были работящими людьми. Они соблюдали незыблемые правила взаимовыручки, в том числе для бездетных. Каждая семья должна была иметь детей, наследников. Поэтому детей отдавали на воспитание. Причем никаких жалоб, недовольства никогда по этому поводу никто не смел высказывать. Также умели хранить свои тайны, может благодаря этому наш отец избежал преследований из-за родного отца Кошкар-оола, которого считали врагом народа. Тем не менее, ему не суждено было вступить в колхоз, так как он считался сыном «феодалки». Больше времени работал у золотарей каюром, проводником, которые располагались в верховье р. Эйлиг-Хем. Имел много русских друзей из числа бывших золотарей. Когда в Шагонаре организовали машинно-тракторную станцию (МТC), многие семейные золотари перешли туда. Наш папа как местный работал с ними. Колхоз, как правило, рассчитывался мелким скотом. В 1954 г., когда сменилось правление колхоза, новое начальство приняло папу на работу в колхоз. Сначала он работал прицепщиком на тракторе, затем наш дед уступил ему свою отару. Отец был в передовиках, даже был депутатом местного совета нескольких созывов. Его фотография частенько висела на доске почета перед райкомом партии.

\section{Родословная}

Авторитет нашей бабушки у родных перешел от матери к нашему отцу. Он был не такой требовательный, но, тем не менее, төрел бөлүк (родом, родственной группой) управлял. Он был в курсе дел каждой семьи, с ним советовались, он помогал материально и учил премудростям жизни. Может поэтому, кожа аал (соседи) его звали Чазак (правитель). Его сажали на почетное место в юрте, угощали свежесваренным тувинским чаем, угощали, как члена хүндүткелдиг бөлүк (знатного) рода Кыргыс дөш (грудинкой барана), подносили как имущему ужа (курдюк) барана.

По мнению отца, төрелим (своей родней) считаются кровные (биологические) родственники, а также приемные родные.

Если раньше у тувинцев основной формой передачи информации о родных - была устная традиция, то сегодня это стало большой проблемой. В наше время есть миграция населения по Туве и за пределы республики. Молодое поколение, порой плохо говорящее на своем родном языке, остается без информации о своих корнях. Учитывая это, моя сестра Лидия Кыргысовна (учитель высшей категории), Валентина Одурековна (внучка Көк, известный, заслуженный человек в Туве, долгие годы была директором школы № 9 г. Кызыла) и я - мы решили собрать детей, внуков, правнуков родных по крови Кыргыс из Эйлиг-Хема. Такое мероприятие удалось впервые организовать в августе 2011 г. (фото 3). Каждая семья тогда поделилась информацией о себе, о своих детях.

Большая часть моей информации была получена от моих родителей, восстановлена по воспоминаниям. Мама любила рассказывать нам, детям, про своих родных. Родственников по отцу мы больше знали со стороны дедушки (приемного отца папы). Бабушка перед смертью решилась открыть папе тайну, что он приемный сын, кто его кровные родные, просила, чтоб он и мы, его дети общались с ними. После этого папа, конечно, старался сблизиться с родными. 


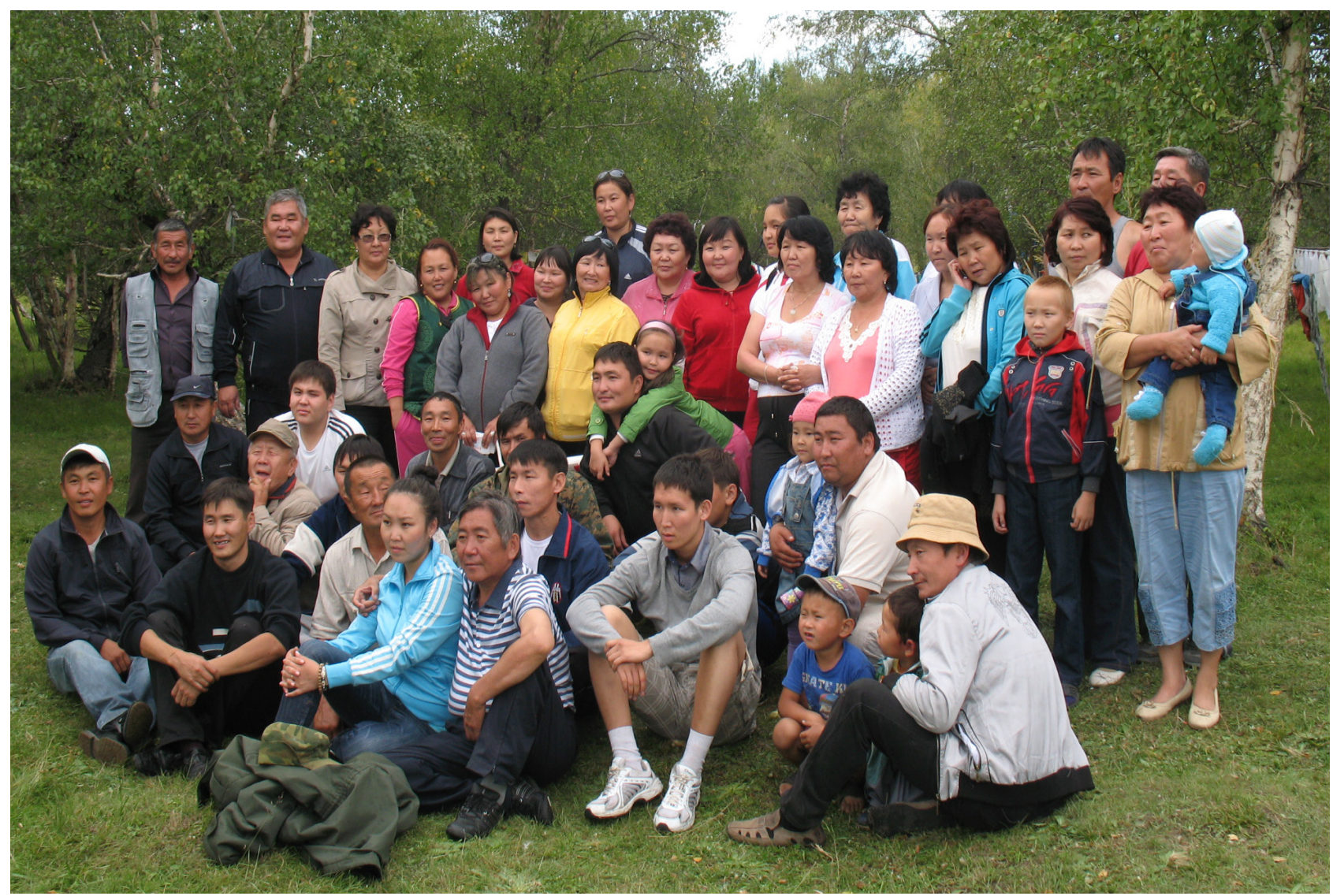

Фото 3. Род Кыргыстар, 2011 г. Фото автора.

Photo 3. The kinship of Kyrgys, 2011. Photo is by the author.

Очень многое помнит и рассказывает моя старшая сестра Лидия Кыргысовна. Генеалогическое древо нашей семьи составлено по ее эскизам (рис. 2). У наших родителей на сегодняшний день от девяти детей есть 26 уйнуктар-бирги салгал - внуков, 48 уйнуктар-ийиги салгал - правнуков и 8 уйнуктар-ушку салгал - праправнуков. Преимущественно все они проживают в Кызыле. Ак-Довураке, Чадаане, Шагонаре. Есть и за пределами Тувы. В наших родных местах жили и работали сестры Унуш (1952-2003) и Рита (1961 г.р.). Они стали передовиками-чабанами. Сестра Рита получила звание «Заслуженный чабан Тувы» в 2005 г., когда учредили такое звание в республике. В настоящее время ее младший сын является животноводом-тысячником Улуг-Хемского района.

Несколько слов о наших старших родных из рода Сат.

Улуг даай-ававыс (старшая сестра мамы) Суваң была хам (шаманкой). Ее так и называли Хам кадай. Хотя наша мама слово хам не употребляла применительно к тете, а говорила караң көрнүр 'человек с даром ясновидения', а также с бургандан чаяган салым 'дарованным Богом способностью'.

В советское время не было принято об этом говорить, но о ее способностях знали близкие и земляки. Она так и жила в долине р. Хем-Теректиг (выше по течению Енисея от Уры), на том же берегу, на территории Красноярского края. Муж был из рода Сат. Она не пользовалась шаманскими атрибутами, не носила специальных одеяний, просто смотрела на человека и ставила диагнозы, давала советы.

По рассказам матери, раскрытие шаманских способностей у нее происходило очень болезненно и проблематично для семьи. Когда моей маме было лет 5, ее сестре Сиилин 8 лет, она им рассказывала о том, что однажды разговаривала с овцой: «На косогоре я чуть было не упала, впереди меня шла овца. Она, повернув голову, сказала: “Как так, у меня круглая ступня и я не падаю, а у человека плоская он падает?”». Настрого наказала сестренкам никому не рассказывать об этом. Они молчали до того момента, когда старшая сестра начала исчезать в тайге по нескольку дней. Родителям пришлось позвать 


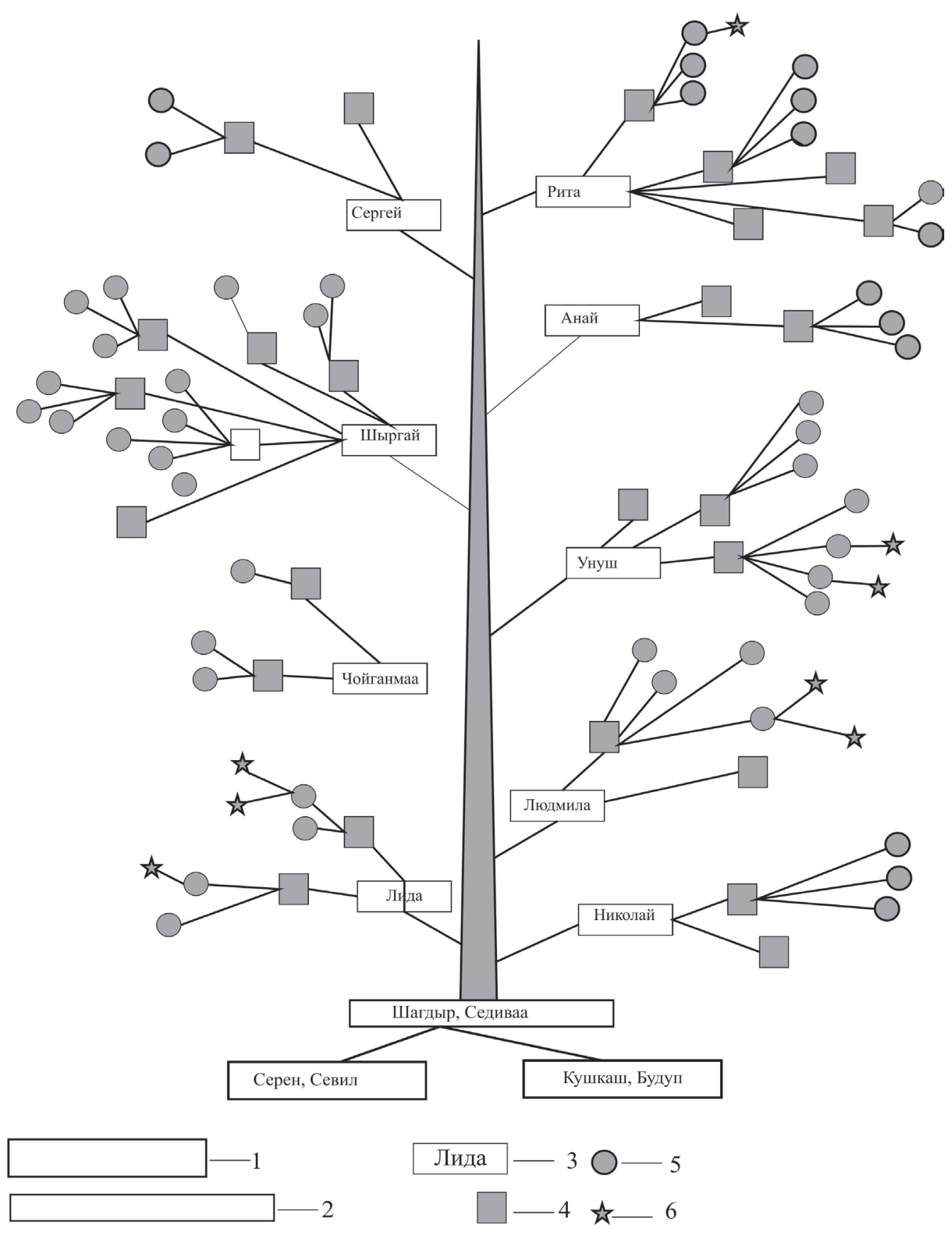

Рис. 2. Родословное древо семьи Шагдыр. Составлено автором.

Fig. 2. The genealogical tree of the family of Shagdyr. Compiled by the author.

хамнар (шаманов) и под звуки дүңгүр (бубна) она вышла однажды из тайги в танце. Взрослые пришли к заключению, что ребенок «не простой». С тех пор она перестала исчезать, но начала говорить то, что обычно видят и слышат шаманы. Такие случаи шаманских историй исследованы В. И. Харитоновой (Харитонова, 2001, 2018). Мама считала ее дар тяжелой ношей.

После введения паспортизации она стала Суван Сат Сереновна, причем все ее дети носили эту фамилию - Суван. Старший сын-Шагдыр живет в Тожу (жена его оттуда родом, у них двое детей), средний Алдын-оол жил в Улуг-Хемском районе (трое детей, живут в Шагонаре), младший, Слава, после женитьбы вернулся в родную долину. Он унаследовал способности мамы. Рано ушел из жизни. Двое детей его живут там же. 


\section{НОВЫЕ ИССЛЕДОВАНИЯ ТУВЫ}

www.nit.tuva.asia
№4

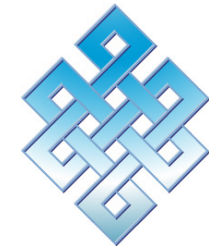

THE NEW RESEARCH OF TUVA

2021

Novye issledovaniia Tuvy

Другая наша тетя Сиилин даай-ававыс была сосватана в долину реки Шом-Шум (левый приток p. Хемчик), в род Ховалыг. По документам она стала Ховалыг Сиилин Сатовна. В годы советской Тувы она с мужем Ховалыгом Чолдак-оолом работали чабанами в совхозе «Ийме». Долгие годы своих детей у них не было, они воспитали двоих приемных - дочь и сына. Дочь Монгуш Хербек Чолдак-ооловна стала матерью-героиней - родила и воспитала 10 детей. Преимущественно проживают в г. Чадаане, с. Ийме (Чоон-Хемчикский район). У сына Ховалыга Делгер-оола Чолдак-олоовича родилось 9 детей. Только в 37-летнем возрасте тетя сама родила дочь Ларису (она сейчас живет в Кызыле).

Младший брат мамы по документам стал Дашом Сатом Сереновичем (1922-1965). Он жил в с. ЧааХоле (ныне Чаа-Хольский район), работал в милиции. У него родилось 7 детей. Сын Даш Анатолий Сатович - учитель в Чаа-Хольской школе, член Союза художников России. Там же живут старший его брат, Николай и сестра Александра, пенсионеры. А остальные - в Шагонаре (Сергей); Кызыле (Клава, Слава, Олег).

Так, по документам получилось, что родные сестры и брат стали вроде бы как посторонние люди. Но мы - их дети - несмотря на эту путаницу при паспортизации, знаем наше родство, общаемся. И мы постарались восстановить нашу родословную, учитывая эти особенности истории.

Семья моих родителей Шагдыр была большая, мы были окружены любовью и заботой. У родителей не было привычки ругаться. Казалось, что они попросту не знали грубых слов. Чужие проблемы не комментировали. Как бы тяжело не было, родители хотели, чтоб все получили хорошее образование.

Мама была большим мастером, обшивала всех. Выделывала мех, делала кожаные изделия, плела нити разной толщины из сухожилей скота. Самой ценной вещью у нас дома была швейная машина марки «Зингер», купленная отцом на деньги облигации. Старшую сестру мама быстро научила на ней работать. Сестра хотела затем работать швеей, но родители отговорили ее, и она стала учительницей начальных классов.

Когда начали строить село Эйлиг-Хем в 1949 г. желающих умельцев приглашали на работу в строительстве. Пригласили и Донгак Дакыр-оола - мужа нашей Седип кырган-ававыс (сестры папы), он был

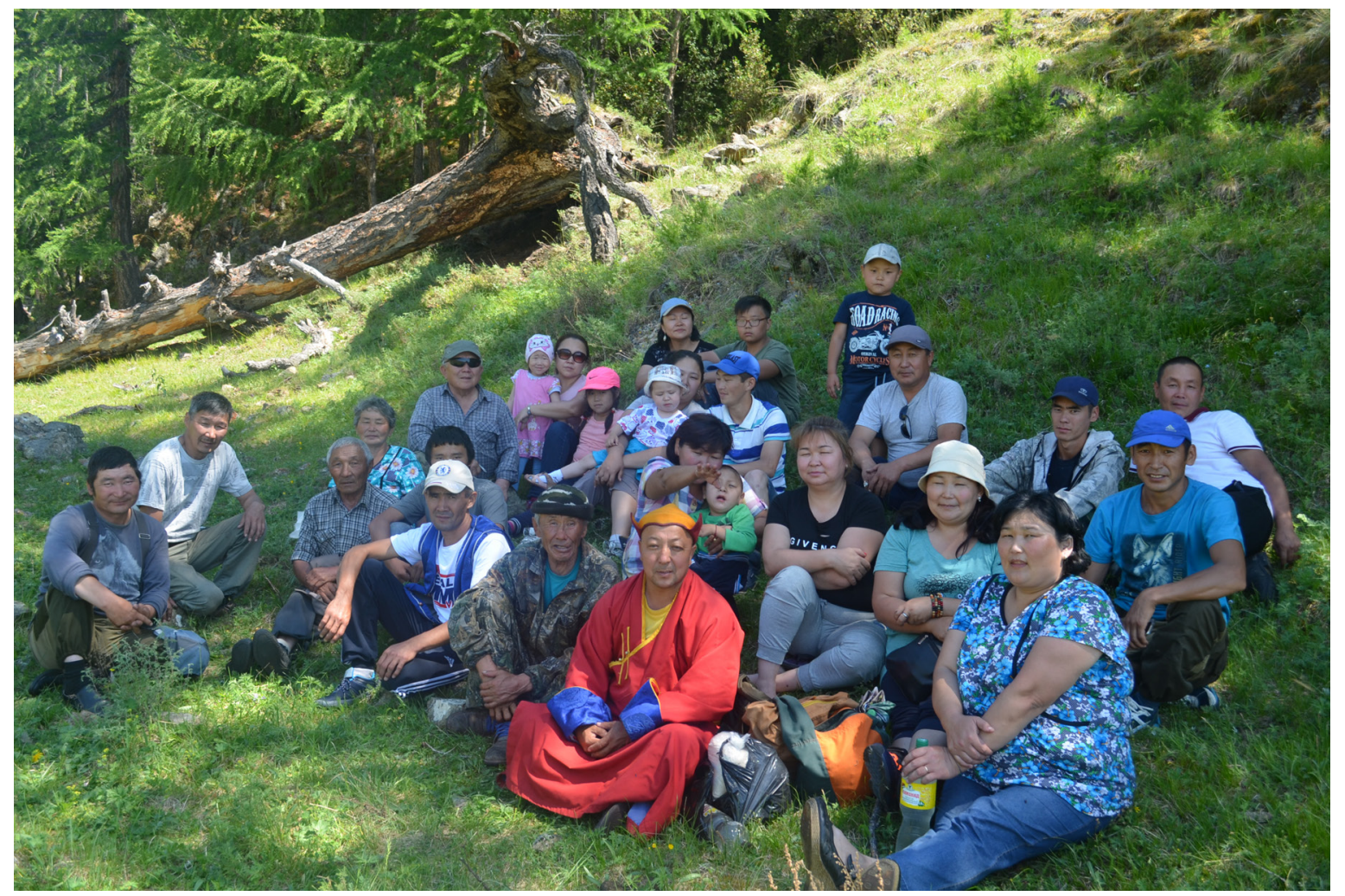

Фото 4. Дагылга, 2017 г. Кыргыстар уязы, Тостеек. Фото из архива автора.

Photo 4. Dagylga, 2017. Kyrgys's nest, Tosteek. Photo from the author's archive. 
кузнецом. В этой связи, у старших детей нашей семьи появилась возможность жить у них и учиться во вновь построенной школе. Семья сестры папы для моих родителей была надежной опорой.

Мы также учились в школе-интернате № 2 г. Шагонара. В итоге 6 детей получили аттестат зрелости в этой школе. Затем, четверо получили высшее образование: Кызыльский пединститут окончила Лидия, инженером экономистом стала Людмила, а Сергей - инженером теплоэнергетиком после окончания Красноярского политехнического института. Я стала инженером геологом, отучившись в Институте цветных металлов г. Красноярска. Двое имеют среднее специальное образования: окончил торговый техникум Анай, сельхозтехникум - Шыргай. И двое стали передовиками-чабанами со средним образованием - Унуш и Рита.

Старший брат Николай проучился всего 6 классов, далее не захотел, уговоры не помогли. Очень много читал, любил фантастику. Рано ушел из жизни из-за несчастного случая.

Мы стараемся не терять связи друг с другом, встречаемся ежегодно на родовых обрядах дагылга, которые проводим в Кыргыстар уязы - родовом гнезде Кыргысов (м. Тостеек, Улуг-Хемский район). Там сохранились только коновязь. Но, начиная с 2013 года, каждый год в середине лета мы проводим там обряд дагылга. В первый раз мы пригласили хам (шамана) Кара-оола Тюлюшовича Допчун-оола. Он показал порядок действий, форму обрядового костра саң салыр. Сейчас обряд проводим без шамана или ламы. Проводим игры, конкурсы, спортивные мероприятия (фото 4). Каждый раз собирается примерно 30-40 человек.

\section{Заключение}

Каждая история семьи тувинцев неразрывно связана с историей Тувы и то, что с нами происходило, является страничкой общего событийного ряда.

В данной работе изложена родословная моей семьи в том виде, в котором ее хранит моя память, дополненная воспоминаниями моих родных. Наш род имеет свою родословную. Нам дороги наши традиции, привычки, культура общения, порядки в любом деле, переданные родителями и их родителями. Мы стараемся привить это своим детям, чтоб они ценили и хранили. Но сегодня, чтобы передать информацию - одной устной формы, которой пользовались наши предки, недостаточно. Нужна фиксация, нужны поиски, надо постоянно все записывать и хранить, и потом уже дополнять, передавать. Поэтому история нашего рода будет еще дописываться, теперь уже нашими детьми и внуками.

\section{СПИСОК ЛИТЕРАТУРЫ}

Грач, А. Д., Савинов, Д. Г., Длужневская, Г. В. (1998) Енисейские кыргызы в центре Тувы (Эйлиг-Хем III как источник по средневековой истории Тувы). М. : Фундамента-Пресс. 84 с.

Дацышен, В. Г. (2005) Саянский рубеж. Южная часть Приенисейского края и русско-тувинские отношения в $1616-1911$ гг. Томск : STT. 250 с.

Кенин-Лопсан, М. Б. (2006) Традиционная культура тувинцев : пер. с тув. Кызыл : Тувинское книжное издательство. 232 с.

Самбуу, И. У. (1992) Тыва оюнар [Тувинские игры]. Кызыл : Тыванын ном ундрер чери. 108 с. (На тув. яз.).

Харитонова В. И. (2001) Некоторые проблемы воздействия шамана, колдуна, целителя на человека и окружающую среду // Экология и традиционные религиозно-магические знания: Материалы международного интердисциплинарного научно-практического симпозиума / отв. ред. В. И. Харитонова М. : ИЭА РАН. 304 с. С. 43-54.

Харитонова, В. И. (2018) Неошаманизм как культовая и целительская практика в современном мире // Новые исследования Тувы. № 4. С. 47-76. DOI: https://www.doi.org/10.25178/nit.2018.4.3

Харунова, М. М.-Б., Харунов, Р. Ш., Базыр, Р. Н. (2020) Государственные внутренние займы Тувинской Народной Республики и СССР в Туве (1920-1940 гг.) // Новые исследования Тувы. № 3. С. 20-34. DOI: https://www.doi. org/10.25178/nit.2020.3.2 


\section{REFERENCES}

Grach, A. D., Savinov, D. G. and Dluzhnevskaia, G. V. (1998) Eniseiskie kyrgyzy v tsentre Tuvy (Eilig-Khem III kak istochnik po srednevekovoi istorii Tuvy) [The Yenisei Kyrgyz in the center of Tuva (Eylig-Khem III as a source on the medieval history of Tuva)]. Moscow, Fundamenta-Press. 84 p. (In Russ.).

Datsyshen, V. G. (2005) Saianskii rubezh. Iuzhnaia chast’ Prieniseiskogo kraia i russko-tuvinskoe otnosheniia v 1616-1911 gg. [The Sayan frontier. The southern part of the Yenisei Region and Russian-Tuvan relations in 1616-1911]. Tomsk, STT Publ. 250 p. (In Russ.).

Kenin-Lopsan, M. B. (2006) Traditsionnaia kul'tura tuvintsev [Traditional culture of Tuvans] / transl. from Tuvan. Kyzyl, Tuvan Book Publisher. 232 p. (In Russ.).

Sambuu, I. U. (1992) Tyva oiunar [Tuvan games]. Kyzyl, Tuvan Book Publisher. 108 p. (In Tuv.).

Kharitonova V. I. (2001) Nekotorye problemy vozdeistviia shamana, kolduna, tselitelia na cheloveka i okruzhaiushchuiu sredu [Some issues of the influence of a shaman, sorcerer, healer on humans and the environment]. In: Ekologiia $i$ traditsionnye religiozno-magicheskie znaniia [Ecology and traditional religious and magical knowledge] : Proceedings of the International interdisciplinary research-to-practice symposium / ed. by V. I. Kharitonova. Moscow, Institute of Ethnology and Anthropology RAS. 304 p. Pp. 43-54. (In Russ.).

Kharitonova, V. I. (2018) Neoshamanizm kak kul'tovaia i tselitel'skaia praktika v sovremennom mire [Tuvan (neo) shamanism as a religious and healing practice in contemporary world]. New Research of Tuva, no. 4, pp. 47-76. (In Russ.). DOI: https://doi.org/10.25178/nit.2018.4.3

Kharunova, M. M.-B., Kharunov, R. Sh. and Bazyr, R. N. (2020) Gosudarstvennye vnutrennie zaimy Tuvinskoi Narodnoi Respubliki i SSSR v Tuve (1920-1940 gg.) [Tuvan People’s Republic's and USSR's domestic loans in Tuva, 1920s - 1940s]. New Research of Tuva, no. 3, pp. 20-34. (In Russ.). DOI: https:/doi.org/10.25178/nit.2020.3.2

Submission date: 03.06.2021. 